ARTIKEL RISET

\title{
Karakteristik Mahasiswa Terhadap Pengembangan Modul Pembelajaran Kimia Berbasis STEM pada Topik Pakan Ayam Buras di Abad 21
}

\section{Student Characteristics of The Development of Chemistry Learning Module Based STEM to Food Freme Chicks in The $21^{\text {st }}$ Century}

\author{
M Sukaryawan $^{1 *}, \mathrm{~K} \mathrm{~A} \mathrm{~W}^{1}$, and J Mujamil ${ }^{1}$ \\ ${ }^{1}$ Pendidikan Kimia, Universitas Sriwijaya, Jl. Palembang-Prabumulih, Kabupaten Ogan Ilir, Indralaya, \\ Sumatera Selatan, Indonesia. 30662. \\ *made_sukaryawan@fkip.unsri.ac.id
}

ARTICLE INFO

Received on:

30 September 2021

Revised till:

19 November 2021

Accepted on:

24 November 2021

Publisher version published on:

25 November 2021

\begin{abstract}
Students need modules in $21^{\text {st }}$ century learning, especially in entrepreneurship courses. The study aims to describe the characteristics of students towards the Integrated Chemistry Learning Module STEM Entrepreneurship Course in Chemistry Education Sriwijaya University, the topic of Feed for Increasing Non-Racial Chicken Eggs. This research was conducted on third semester student of in Chemistry Education Sriwijaya University with a descriptive method. The research data were collected using a valid questionnaire with a reliability coefficient of 0.925 , interviews and documentation. The results of the study show that the characteristicts of student are very suitable/enable/feasible to compose a learning module on the topic of Increasing Non-Racial Chicken Eggs, in the $21^{\text {st }}$ century. Student responded agree and strongly agree to use this module respectively by $57.8 \%$ and $42.2 \%$. Respondents agree and strongly agree that they are accustomed to using Android/Internet/laptop phones, respectively, by $62,2 \%$ and $34,4 \%$.
\end{abstract}

\section{KEYWORDS}

$21^{\text {st }}$ Century, Characteristicts of Student, Food Freme Chicks Topic

\begin{abstract}
ABSTRAK
Mahasiswa membutuhkan modul untuk pembelajaran abad 21 terutama pada mata kuliah kewirausahaan. Penelitian ini bertujuan untuk mendeskripsikan karakteristik mahasiswa terhadap Modul Pembelajaran Kimia terintegrasi STEM Mata Kuliah Kewirausahaan di Pendidikan Kimia FKIP Universitas Sriwijaya, topik Pakan untuk Peningkatan Telur Ayam Bukan Ras. Penelitian ini dilakukan kepada mahasiswa semester tiga Pendidikan Kimia FKIP Universitas Sriwijaya dengan metode deskriptif. Data penelitian dikumpulkan menggunakan angket yang valid dengan koefisien reliabilitas 0.925 , wawancara dan dokumentasi. Hasil penelitian memperlihatkan bahwa karakteristik mahasiswa sangat sesuai/memungkinkan/ layak untuk menyusun modul pembelajaran topik Peningkatan Telur Ayam Bukan Ras, di abad ke-21. Mahasiswa merespon setuju dan sangat setuju akan menggunakan modul ini masing-masing sebesar 57,8\% dan $42,2 \%$. Responden setuju dan sangat setuju terbiasa menggunakan HP Android/Internet/laptop masing-masing sebesar $62,2 \%$ dan $34,4 \%$.
\end{abstract}

KATA KUNCI

Abad Ke 21, Karakteristik Mahasiswa, Topik Pakan Ayam Buras 


\section{PENDAHULUAN}

Hasil studi awal penelitian menunjukkan bahwa $60 \%$ responden menjawab sangat setuju dibutuhkan modul untuk pembelajaran abad ke-21. Hasil analisis kurikulum menunjukkan bahwa perlu dilakukan revisi kurikulum mata kuliah Kewirausahaan di Pendidikan Kimia FKIP Universitas Sriwijaya menyesuaikan dengan pembelajaran abad ke-21. Pembelajaran abad ke-21 yang berpusat pada peserta didik/mahasiswa berbeda dengan pembelajaran yang berpusat pada pendidik, berikut karakter pembelajaran abad 21: 1) pembelajaran berpusat pada mahasiswa, 2) HOTS (Higher Order Thinking Skills), 3) komunikasi, 4) adaptif, 5) kerja sama, 6) berpikir kritis, 7) kreatif, 8) pemecahan masalah, 9) daya cipta, dan 10) inovasi.

Topik Pakan untuk Peningkatan Produktivitas Telur Ayam Buras menjadi penting dalam penelitian ini $^{[1]}$ dan telah dilakukan perbaikan pakan ayam buras petelur ${ }^{[2]}$. Selanjutnya untuk mengatasi kelemahan penelitian sebelumnya mengenai penggemukan sapi $^{[3]}$ dan budidaya ikan lele ${ }^{[4]}$ tidak menguntungkan dalam hal waktu jual. Sapi umumnya di jual pada waktu lebaran Idul Adha dan harus ada mitra dengan pengurus masjid. Sapi dijual di pasar juga dikehendaki memiliki jaringan atau koneksi. Ikan lele harus dijual setelah 3 bulan pemeliharaan, setelah 3 bulan ikan lele akan kanibal, saling makan sesamanya, dan bobot ikan lele tidak bertambah lagi, maka jumlah pakan ikan itu akan lebih banyak, sehingga akan merugi jika harus dijual setelah 3 bulan budidaya atau pemeliharaan ikan itu.

Jumlah bahan ajar, modul, atau e-modul mata kuliah Kewirausahaan di Pendidikan Kimia FKIP Universitas Sriwijaya yang "adaptif" ${ }^{[5]}$ di era pembelajaran abad ke-21, masih kurang dan perlu ditambah. Selanjutnya disarankan dari hasil penelitian itu bahwa perlu dilakukan penelitian lanjutan berupa Analisis Karakteristik Mahasiswa terhadap pengembangan modul Pembelajaran Kimia Terintegrasi Science, Technology, Engineering, and Mathematic (STEM) Mata Kuliah Kewirausahaan Pendidikan Kimia FKIP Universitas Sriwijaya, Topik Pakan untuk Meningkatkan Produktivitas Telur Ayam Buras, era abad ke-21. Pada abad ke-21 diperlukan metode pembelajaran ${ }^{[6]}$, yang membuat mahasiswa kreatif. Mahasiswa kreatif dapat belajar dengan menggunakan pendekatan $\mathrm{STEM}^{[7]}$ dan telah berhasil diteliti ${ }^{[8]}$. Perlu dilakukan peningkatan produktivitas ayam buras dikarenakan untuk menutupi kelemahan penelitian sebelumnya tentang penggemukan sapi, kelemahan dalam hal pemasaran sapi sangat terbatas di masa hari raya kurban dan harus ada relasi dengan pengurus masjid. Telur ayam buras lebih mudah dan murah dijual untuk dipasarkan dibandingkan dengan sapi ${ }^{[3]}$.

Tujuan penelitian ini adalah mendeskripsikan, menganalisis karakteristik dan "kesiapan"[9] mahasiswaterhadappenggunaanmodulpembelajaran kimia terintegrasi STEM mata kuliah Kewirausahaan Pendidikan Kimia FKIP Universitas Sriwijaya, topik Pakan untuk Meningkatkan Produktivitas Telur Ayam Buras, era abad ke-21. Penelitian ini bermanfaat sebagai: 1) alternatif peluang wirausaha alumni Pendidikan Kimia, selain menjadi guru kimia di SMA/MA/SMK. 2) peningkatan hasil belajar mata kuliah Kewirausahaan dan Indeks Prestasi Kumulatif mahasiswa. 3) penurunan masa studi mahasiswa di Pendidikan Kimia FKIP Universitas Sriwijaya. 4) peningkatan kualitas Program Studi Pendidikan Kimia FKIP Universitas Sriwijaya. 5) sumber rujukan bagi peneliti lain untuk mengembangkan penelitian di bidang kewirausahaan.

Analisis karakteristik mahasiswa ini merupakan bagian dari penelitian pengembangan Model ADDIE (Analysis, Design, Development, Implementation, and Evaluation). Analysis itu terdiri atas analisis kebutuhan, analisis kurikulum, dan analisis karakteristik mahasiswa ${ }^{[10]}$. Pembelajaran era Abad ke-21 memiliki ciri khusus yaitu mahasiswa kreatif ${ }^{11]}$, kritis $^{[12]}$, adanya motivasi ${ }^{[13]}$, kemauan, keberanian ${ }^{[14]}$, gaya belajar ${ }^{[15]}$, kemampuan memecahkan masalah, dihubungkan dengan dunia nyata, inovasi, inisiatif, fleksibel, adaptif dan berkomunikasi, menggunakan media ICT, menguasai teknologi informasi, serta berkolaborasi ${ }^{[16]}$. Pada pembelajaran abad ke-21, karakteristik siswa juga menentukan metode, model, atau pendekatan pembelajaran. Salah satu metode atau pendekatan yang sesuai dengan pembelajaran abad 21 adalah pendekatan STEM.

\section{METODE}

Metode penelitian ini adalah deskriptif dengan teknis pengambilan data berupa penyebaran angket, wawancara dan dokumentasi. Alur penelitian ini terdiri atas: a) studi pustaka, dan analisis sehingga didapat proposal penelitian, b) penyusunan instrumen penelitian: angket penelitian, wawancara, dan dokumentasi, c) validasi instrumen penelitian, d) Pengambilan data penelitian, e) analisis data penelitian, dan f) pengambilan kesimpulan penelitian, g) rekomendasi hasil penelitian. Angket penelitian ini modifikasi dari angket dari TOSRA oleh Fraser ${ }^{[2]}$. Validasi dan reliabilitas instrumen angket dihitung menggunakan program SPSS (Statistical Product and Service Solutions). Apabila validitas dan reliabilitas hitung lebih besar dari validitas dan reliabilitas tabel, maka instrumen itu valid dan reliabel ${ }^{[17]}$. Pada penelitian ini dilakukan penyusunan instrumen penelitian berupa angket penelitian, wawancara, dan dokumentasi, sebagai triangulasi data.

\subsection{Angket}

Tahap ini disusun angket, kemudian dilakukan validasi ahli terhadap angket itu. Angket itu diberikan atau disebarkan kepada responden mahasiswa untuk diambil data validasi instrumen penelitian.

\subsection{Wawancara}

Tahap ini dilakukan wawancara kepada responden atau mahasiswa untuk menggali atau melengkapi alasan responden mahasiswa menjawab angket tersebut. Wawancara juga dilakukan kepada Koordinator Program Studi Pendidikan Kimia FKIP Universitas Sriwijaya dan dosen pengampu mata kuliah Kewirausahaan. 


\subsection{Dokumentasi}

Pada tahap ini dilakukan pengambilan data dokumen. Data dokumen didapat dari arsip di Program Studi Pendidikan Kimia dan dosen pengampu mata kuliah Kewirausahaan.

\section{HASIL DAN DISKUSI}

\subsection{Angket}

Angket penelitian ini modifikasi dari angket Fraser ${ }^{[18]}$. Ada 90 item atau butir pernyataan dalam instrumen angket, setelah dilakukan validasi ahli berinisial RE. Terdapat 18 butir item yang direvisi ulang oleh pakar atau ahli RE, yang selanjutnya angket di gunakan untuk uji coba. Hasil uji coba angket secara keseluruhan maka didapat skor validitas angket setuju dan sangat setuju dengan rata-rata 4,33 (skala 1 sangat tidak setuju sampai dengan 5 sangat setuju). Skor reliabilitas angket adalah 0,925 termasuk kategori tinggi.

Angket Karakteristik Mahasiswa terhadap Modul Pembelajaran Kimia Terintegrasi STEM Mata Kuliah Kewirausahaan Topik Pakan untuk Peningkatan Telur Ayam Buras adalah reliabel. Hal ini berarti angket itu dapat digunakan untuk menjaring data penelitian tentang Karakteristik Mahasiswa terhadap Modul Pembelajaran Kimia Terintegrasi STEM Mata Kuliah Kewirausahaan FKIP Universitas Sriwijaya, Topik Peningkatan Produktivitas Telur Ayam Buras. Hasil itu, bahwa mahasiswa setuju dan sangat setuju menggunakan modul ini masing-masing sebesar $57,8 \%$ dan $42,2 \%$. Responden ragu-ragu, setuju dan sangat setuju terbiasa menggunakan HP Android/ Internet/ laptop/belajar dengan menggunakan e-learning/WhatsApp masing-masing sebesar 3,34\%; $62,2 \%$ dan $34,4 \%$. Data hasil penelitian inilah dapat dijadikan rekomendasi bahwa Modul pembelajaran kimia ini cocok, sesuai dengan karakteristik, sikap, kebiasaan mahasiswa dan akan dipakai atau digunakan modul itu oleh mahasiswa nantinya.

Rekomendasi dan saran selanjutnya penelitian pengembangan modul ini untuk dapat dilanjutkan, yaitu penyusunan instrumen atau perancangan atau desain modul menjadi draf modul atau spesifik prototipe. Selanjutnya disusun pula instrumen validasi untuk memvalidasi spesifik prototipe itu.

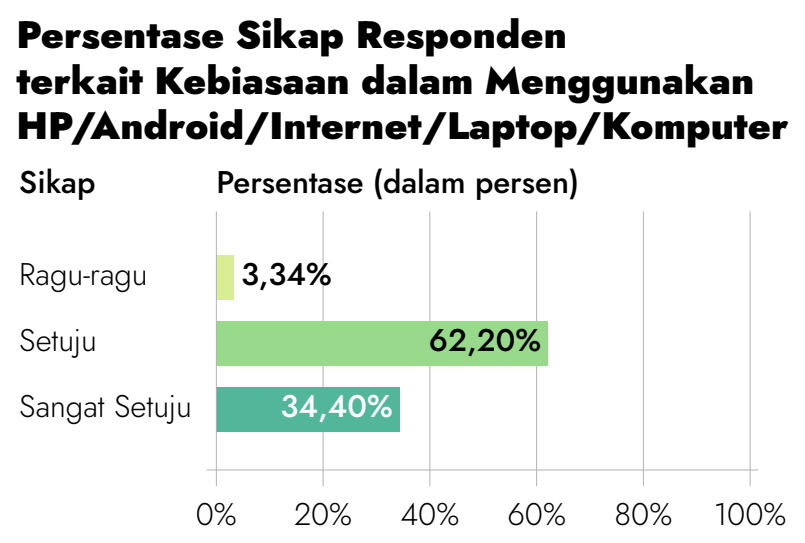

Gambar 1. Persentase sikap responden Ragu-ragu, Setuju dan Sangat Setuju.
Informasi dari Gambar 1 bahwa persentase sikap responden Ragu-ragu, Setuju dan Sangat Setuju akan belajar mandiri menggunakan modul Pembelajaran Kimia Terintegrasi STEM Mata Kuliah Kewirausahaan Topik Pakan untuk Peningkatan Telur Ayam Buras adalah 3,34\%; 62,2\% dan 34,4\%. Hal ini berarti modul itu yang akan dikembangkan dapat digunakan oleh responden nantinya.

Tabel 1. Sikap Responden terhadap Beternak Ayam Buras untuk meningkatkan Produktivitas Telur Ayam Buras

\begin{tabular}{c|c|c} 
Skor & Jumlah & Persen \\
\hline 4 & 58 & 64,4 \\
\hline 5 & 32 & 35,6 \\
\hline Total & $\mathbf{9 0}$ & $\mathbf{1 0 0}$
\end{tabular}

Data dari Tabel 1 menunjukkan bahwa responden setuju akan beternak ayam buras untuk meningkatkan produktivitas telur ayam buras adalah setuju dan sangat setuju masing-masing $64,4 \%$ dan $35,6 \%$, tentunya dengan persyaratan magang dahulu kepada peternak yang telah berhasil, sebelum terjun langsung beternak ayam buras petelur, supaya cepat berhasil. Hal ini berarti modul yang akan dikembangkan itu akan dimanfaatkan oleh responden nantinya. Tabel 2 itu dalam bentuk grafik batang seperti Gambar 2.

\section{Persentase Sikap Responden terkait “Beternak Ayam Buras, akan Meningkatkan Produktivitas Telur Ayam Buras"}

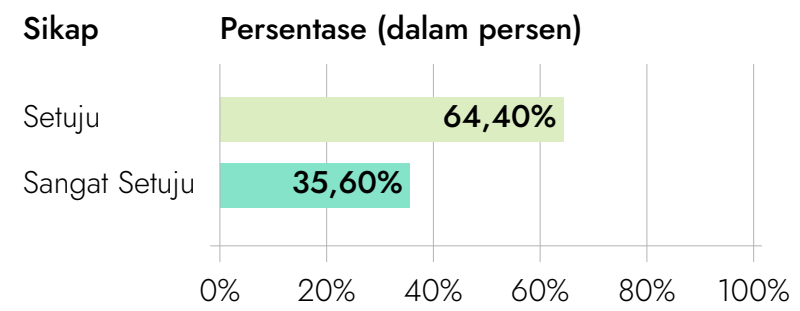

Gambar 2. Sikap Responden terhadap Beternak Ayam Buras untuk meningkatkan Produktivitas Telur Ayam Buras.

Tabel 2. Sikap Responden terhadap Akan Menggunakan Modul Beternak Ayam Buras untuk meningkatkan Produktivitas Telur Ayam Buras

\begin{tabular}{c|c|c} 
Skor & Jumlah & Persen \\
\hline 4 & 52 & 57,8 \\
\hline 5 & 38 & 42,2 \\
\hline Total & $\mathbf{9 0}$ & $\mathbf{1 0 0}$
\end{tabular}


Dari Tabel 2 itu mengisyaratkan bahwa responden akan setuju dan sangat setuju menggunakan modul itu. Tabel 2 itu dalam bentuk grafik batang seperti Gambar 3.

\section{Persentase Sikap Responden terkait "Akan Menggunakan Modul Beternak Ayam Buras untuk Meningkatkan Produktivitas Telur Ayam Buras"'}

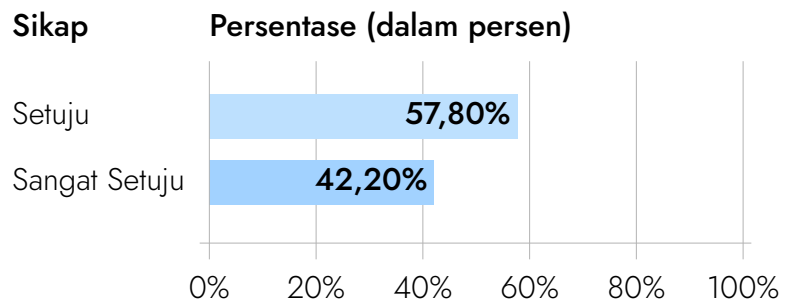

Gambar 3. Sikap Responden terhadap Akan Menggunakan Modul Beternak Ayam Buras untuk meningkatkan Produktivitas Telur Ayam Buras.

Tabel 3. Terbiasa Belajar Mandiri Tanpa Guru/ Dosen

\begin{tabular}{c|c|c} 
Skor & Jumlah & Persen \\
\hline 4 & 66 & 73,3 \\
\hline 5 & 24 & 26,7 \\
\hline Total & $\mathbf{9 0}$ & $\mathbf{1 0 0}$
\end{tabular}

Dari Tabel 3 itu modul itu sangat cocok digunakan oleh responden dikarenakan responden terbiasa belajar secara mandiri. Ciri modul selalu digunakan secara mandiri oleh user. Tabel 3 itu dalam bentuk grafik batang seperti Gambar 4 .

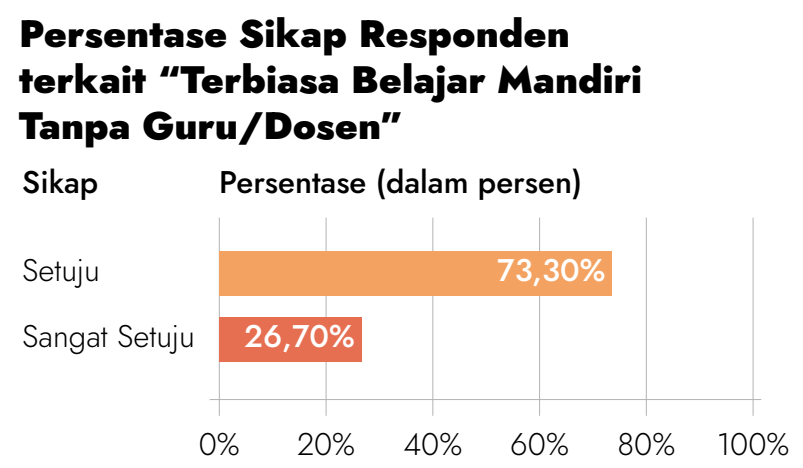

Gambar 4. Responden Terbiasa Mandiri Tanpa Guru/Dosen
Tabel 4. Responden Terbiasa Menggunakan HP Android, Internet, Laptop, Komputer

\begin{tabular}{c|c|c} 
Skor & Jumlah & Persen \\
\hline 3 & 3 & 3,3 \\
\hline 4 & 56 & 62,2 \\
\hline 5 & 31 & 34,4 \\
\hline Total & $\mathbf{9 0}$ & $\mathbf{1 0 0}$
\end{tabular}

Dari Tabel 4 itu bahwa responden terbiasa menggunakan IT/ICT HP Android, Internet, Laptop, Komputer sehingga responden setuju dan sangat setuju akan menggunakan modul itu nantinya. Tabel 4 itu dalam bentuk grafik batang seperti pada Gambar 5.

\section{Persentase Sikap Responden terkait Kebiasaan dalam Menggunakan HP/Android/Internet/Laptop/Komputer}

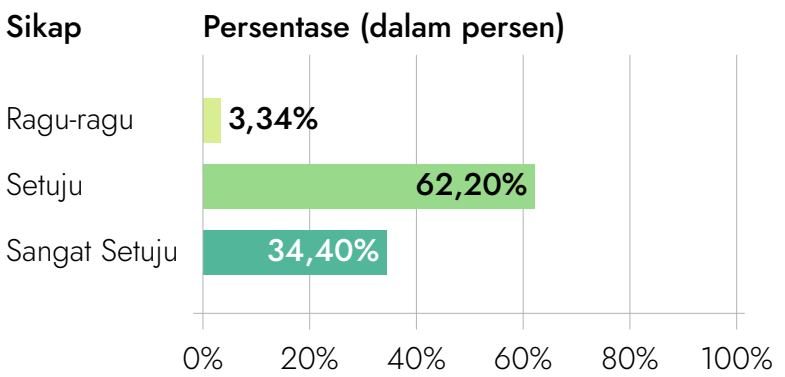

Gambar 5. Responden Terbiasa Menggunakan HP Android, Internet, Laptop, Komputer

Skor 5 berarti sangat setuju, 4 berarti setuju, dan 3 berarti ragu-ragu (3,34\%). Responden raguragu ini karena sering terkendala oleh koneksi internet yang tidak baik.

Tabel 5. Karakteristik Mahasiswa terhadap Modul Pembelajaran Kimia Topil Pakan untuk Meningkatkan Produktivitas Telur Ayam Buras

\begin{tabular}{c|c|c} 
Skor & Jumlah & Persen \\
\hline 4 & 55 & 61,1 \\
\hline 5 & 35 & 38,9 \\
\hline Total & $\mathbf{9 0}$ & $\mathbf{1 0 0}$
\end{tabular}

Data pada Tabel 5 itu sebagai rangkuman bahwa mahasiswa sebagai responden penelitian ini akan setuju $61,1 \%$ dan sangat setuju 38,9\% siap menerapkan belajar mandiri dengan modul itu. Tabel 5 itu dalam bentuk grafik batang seperti Gambar 6 . 


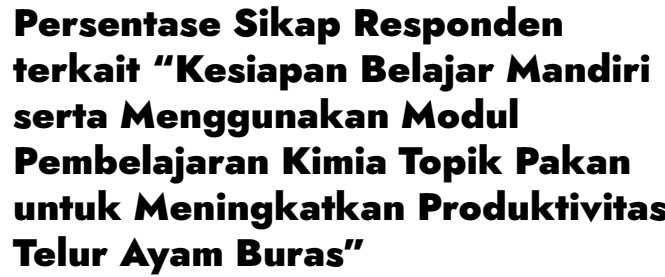

Sikap Persentase (dalam persen)

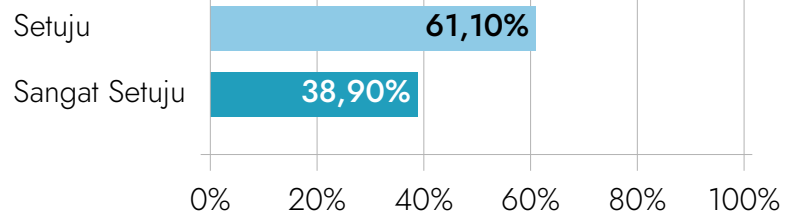

Gambar 6. Karakteristik Mahasiswa terhadap Modul Pembelajaran Kimia Topil Pakan untuk Meningkatkan Produktivitas Telur Ayam Buras

\subsection{Wawancara}

Tahap wawancara ini dilakukan kepada responden mahasiswa, $100 \%$ mereka setuju dan sangat setuju terbiasa menggunakan ICT, HP Android, Internet, Google, Laptop. ICT itu menjadi andalan bagi mahasiswa mengikuti pembelajaran secara daring selama pandemi COVID-19 ini. Dari wawancara itu, hanya saja kendalanya adalah perlu magang terlebih dahulu sebelum terjun langsung berwirausaha ayam buras petelur itu. Responden sangat setuju perkuliahan Kewirausahaan itu, tidak hanya sebatas teori saja ${ }^{[19]}$. Adanya data 3,34\% responden mahasiswa terkendala jaringan internet yang sebagian masih kurang baik.

Wawancara berikutnya adalah kepada dosen pengampu mata kuliah Kewirausahaan "S" dan Koordinator Program Studi Pendidikan Kimia FKIP Universitas Sriwijaya “EN". Hasil wawancara itu berupa pembelajaran dengan menggunakan pendekatan terintegrasi STEM sangat membantu sekali mahasiswa belajar mandiri. Belajar mandiri ini sebagai bekal mahasiswa belajar sepanjang hayat di abad 21 ini. Belajar secara mandiri sepanjang hayat itu sangat dimungkinkan karena sekarang ini big data yang ada di Google sudah sangat terbuka, siapa pun dapat mengaksesnya. Perkembangan manusia dari yang sangat sederhana, ke pertanian/agraris, ke industri, menuju ke masyarakat digital di abad ke-21 ini.

Selanjutnya data berupa Rencana Perkuliahan Semester dan topik-topiknya ada di e-learning Universitas Sriwijaya, karena selama Pandemi COVID-19 ini Universitas Sriwijaya mewajibkan perkuliahan secara daring. Pendidikan dan pembelajaran berkembang dari yang sederhana, pembelajaran berpusat pada guru menuju ke pembelajaran berpusat pada siswa atau mahasiswa. STEM merupakan salah satu pembelajaran yang diawali dengan adanya masalah. Hasil wawancara ini sesuai dengan langkah-langkah STEM yaitu adanya masalah, rencana atau desain pemecahan masalah, uji coba pemecahan masalah, dan pelaporan hasil pemecahan masalah ${ }^{[20]}$. Pelaporan itu secara digital akan lebih sempurna diunggah di Google sebagai ciri dari pembelajaran abad ke-21.

Mata kuliah Kewirausahaan ini dapat menjadi penting untuk menopang pembelajaran abad ke-21 karena berwirausaha dapat menyelesaikan masalah pembelajaran, bahkan masalah ekonomi, kesehatan, dan keamanan. Pembelajaran di era abad ke-21 itu menggunakan "big data" tersimpan di Google. Misalnya reaksi identifikasi karbohidrat secara tes Molisch secara aman didapat di Google ${ }^{[21]}$.

Gambar 7. Gambar 7. Pembentukan Cincin Ungu pada Reaksi Molisch ${ }^{[21]}$.

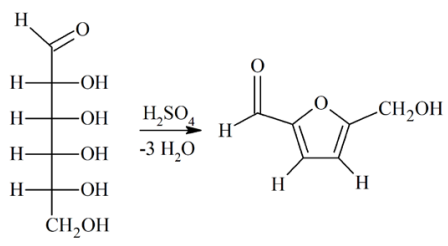

Limbah bahan kimia setelah praktikum di laboratorium akan aman jika menggunakan pembelajaran daring di era abad ke-21 itu, dengan menggunakan big data di Google tersebut.

\subsection{Dokumentasi}

Tahap dokumentasi ini didapat: 1) data Rencana Pelaksanaan Perkuliahan (RPS) Mata Kuliah Kewirausahaan yang telah disusun dan diupload oleh dosen pengampunya telah terhapus dari e-learning Universitas Sriwijaya. 2) RPS terdokumentasi di Program Studi Pendidikan Kimia FKIP Universitas Sriwijaya masih menggunakan format kurikulum lama, namun perlu disesuaikan dengan format kurikulum hasil lokakarya bulan Agustus 2021. 3) Mahasiswa belajar sangat dipengaruhi oleh metode pembelajaran yang disiapkan oleh pengampu mata kuliah. Wirausaha muda akan terbentuk (Muharomah, 2017) manakala menggunakan metode atau model pembelajaran dengan terintegrasi STEM. 4) dalam mata kuliah Kewirausahaan perlu dimasukkan modul pembelajaran kimia terintegrasi STEM di Pendidikan Kimia FKIP Universitas Sriwijaya, topik Pakan untuk Meningkatkan Produktivitas Telur Ayam Buras, karena baru ada 9 judul pokok modul yang ada di Pendidikan Kimia itu sehingga masih diperlukan minimal 4 judul lagi untuk mencapai 13 kali pertemuan. Satu pertemuan digunakan untuk kuliah pendahuluan, 2 pertemuan dipakai untuk ujian tengah semester dan ujian akhir semester, sehingga total menjadi 16 kali pertemuan untuk satu semester.

Topik pokok modul itu berupa: a) penambahan bubuk kunyit untuk peningkatan daya tahan tahu; b) ikan patin; c) ikan nila; d) ikan mas; e) ikan gabus; f) ikan lele; g) ikan gurame. h) sapi; i) pertumbuhan tanaman selada; j) media Tanam Ampas Kopi dan Daun Pisang Kering untuk Jamur Tiram. 5) Menurut Firman (2017) STEM, kreativitas mahasiswa berupa 
a) mahasiswa merancang judul berwirausaha topik jenis pakan Ayam Buras petelur; b) berupa mahasiswa merencanakan alamat berwirausaha, pakan jenis tertentu. Untuk Peningkatan Produktivitas Telur Ayam Buras pada Mata Kuliah Kewirausahaan di Program Studi Pendidikan Kimia Fakultas Keguruan dan Ilmu Pendidikan Universitas Sriwijaya; c) berupa merencanakan dana awal berwirausaha Peningkatan Produktivitas Telur Ayam Buras.; d) Mahasiswa mendownload budidaya ayam buras petelur berupa: video, jurnal, dan praktikum/ prosedur kimia dan mencatat alamat URL video itu, tiap mhs beda videonya; e) mahasiswa melaporkan hasil kegiatan a) sampai dengan e) diketik dengan program word, dikumpulkan ke wa grup dan pada google drive (catatan untuk butir e) cukup tulis alamat URL nya saja). Melalui modul ini diharapkan mahasiswa memiliki sikap senang berwirausaha sebagai usaha sampingan selain menjadi guru kimia. 6) minimal $2 \%$ penduduk suatu negara sebagai wirausahawan maka negara itu akan maju. 7) Topik penelitian untuk mensejahterakan manusia sudah menjadi komitmen Lembaga Penelitian dan Pengabdian kepada Masyarakat Universitas Sriwijaya, jadi kewirausahaan sudah sangat cocok mendukung kegiatan penelitian.

Dari uraian hasil dan pembahasan penellitian itu jelaslah bahwa perlu ditindaklanjuti penelitian untuk menyusun desain modul pembelajaran kimia terintegrasi STEM mata kuliah Kewirausahaan Pendidikan Kimia FKIP Universitas Sriwijaya. Selanjutnya dilakukan penyusunan instrumen validasi isi, pedogogi, dan kepraktisan modul itu sesuai dengan tahap peneleitian pengembangan model ADDIE. Penelitian yang sama juga dilakuakan tentang evaluasi validitas konten dan konstruk bahan ajar topik asam basa ${ }^{[22]}$.

\section{SIMPULAN}

Simpulan dari penelitian ini adalah karakteristik mahasiswa sudah siap untuk belajar secara mandiri, menggunakan HP Android, elearning, whatsApp modul pembelajaran kimia terintegrasi STEM mata kuliah Kewirausahaan di Pendidikan Kimia FKIP Universitas Sriwijaya, topik untuk Peningkatan Produktivitas Telur Ayam Buras.

\section{REFERENSI}

1. Hasjidla NF, Imam C, Agus WW. Optimasi Komposisi Pakan Untuk Memenuhi Kebutuhan Nutrisi Ayam Petelur dengan Biaya Minimum Menggunakan Improved Particle Swarm Optimization (IPSO). Program Studi Teknik Informatika, Fakultas Ilmu Komputer, Universitas Brawijaya. J. Pengembangan Teknologi Informasi dan Ilmu Komputer. 2018.2(1) 1-10.

2. Mangisah I, Bambang S, Fajar W, Nyoman S, Vitus DY. Perbaikan Pakan untuk Meningkatkan Produktivitas Ayam Kampung Super di Kecamatan Plantungan Kabupaten Kendal. Fakultas Peternakan dan Pertanian
Universitas Diponegoro Semarang J. Dianmas. 2018.7 (1) 35-40

3. WKA, Mujamil J, Sukaryawan M. Penggemukan Sapi sebagai Modul Pembelajaran di Abad ke-21. Jurnal Penelitian Pendidikan Kimia: Kajian Hasil Penelitian Pendidikan Kimia. 2020. 7(2): 55-70

4. Zuriyatina R, WKA, Sari DK. Validitas dan Efektivitas Modul Pembelajaran Kimia Terintegrasi STEM-PBL Topik Pakan Jeroan Ikan untuk Ikan Lele dan Topik Lain pada mata Kuliah Kewirausahaan. Jambura Jurnal of Education Chemistry. 2020. 2(2) 48-55.

5. Ary M. Pengklasifikasian Karakteristik Mahasiswa Baru dalam Memilih Program Studi Menggunakan Analisis Cluster. Jurnal Informatika. 2015. 2(1): 181-188

6. Budiningsih CA. Karakteristik Siswa sebagai Pijakan dalam Penelitian dan Metode Pembelajaran. Jurnal Cakrawala Pendidikan. 2011. 30(1): 160-173

7. Firman H. STEM-PBL untuk Pembelajaran kimia Abad ke-21. Seminar National IPA di Palembang. 2017.

8. Ernawati, Rosalina L, Dewi M. Efektivitas E Learning Mata Kuliah Kewirausahaan di Universitas Negeri Padang pada Masa Pandemi COVID 19. Indonesian Journal of Informatic Research and Software Engineering. 2021. 1(1): 9-15

9. Mardhiya J. Pembelajaran Online di Program Studi Pendidikan Kimia : Survei Kesiapan Mahasiswa. Journal of The Indonesian Society Integrated Chemistry. 2021. 13(1): 32-42

10. Aldoobie N. (2015) ADDIE Model, American International Journal of Contemporary Research. 2021.5(6): 68-72

11. Syahrul R, Sumarmin R, Helendra, Yogica R. Analisis Berpikir Kritis Siswa SMAN 4 Padang pada Materi Pencemaran Lingkungan (Jurnal Eksakta Pendidikan). 2021. 5(1): 25-32

12. Nuraini S, Feronika T, Yunita L. Implementasi Self-Efficacy dan Keterampilan Berpikir Kritis Siswa Pada Pembelajaran Kimia di Abad 21. Journal of Educational Chemistry Jambura. 2019.1(2): 49-56.

13. Tenisia I, Sari P, Sylvia E. Analisis Karakteristik Mahasiswa dan Motivasi Belajar terhadap Prestasi Akademik Mahasiswa Entrepreneur Kabupaten Garut. Journal Business Innovation \& Entrepreneurship. 2020. 2(1): 28-40

14. Yulia W, Kusrini DE. Analisis Karakteristik Mahasiswa dan Faktor-Faktor yang Berpengaruh terhadap Kepemilikan Usaha Mandiri Mahasiswa ITS. 2010. Hal 1-12.

15. Sari AK. Analisis Karakteristik Gaya Belajar Visual, Auditorial, Kinestetik Mahasiswa Pendidikan Informatika Angkatan 2014. Jurnal Ilmiah Edutic. 2014. 1(1): 1-12.

16. Sugiyarti L, Arif A, Muslim. Pembelajaran Abad ke-21 di SD. Prosiding Seminar dan Diskusi Nasional Pendidikan Dasar. 2018. Halaman 439-444 
17. Sugiyono. Memahami Penelitian Kualitatif, Bandung: CV. Alfabeta. 2005.

18. Fraser BJ. Test of Science-Related Attitudes. The Australian Council for Educational Research Limited. Handbook. Hawthorn, Victoria 312.1982.

19. Setiawan IPP. Isolasi dan Identifikasi Karbohidrat. 2015.

20. Nengsih NR, Yusmaita E, Gazali F. Evaluasi Validitas Konten dan Konstruk Bahan Ajar Asam Basa Berbasis REACT. Jurnal Edukimia. 2019. 1(1): 1-10

\section{SARAN PENULIS}

Saran dari hasil penelitian ini adalah agar dilanjutkan penelitian ini berupa penyusunan desain modul pembelajaran dan divalidasi sesuai dengan model penelitian pengembangan ADDIE.

\section{UCAPAN TERIMA KASIH}

Terima kasih kepada Rektor Universitas Sriwijaya, yang telah mendanai penelitian/publikasi artikel ini dari: Anggaran DIPA Badan Layanan Umum Universitas SriwijayaTahun Anggaran 2021, Nomor SP DIPA-023.17.2.677515/2021., Sesuai dengan SK Rektor 0022/UN9/SKLP2M.PT/2021 tanggal 21 Juli 2021. 